\title{
Diversity and methane oxidation of active epibiotic methanotrophs on live Shinkaia crosnieri
}

\author{
Tomo-o Watsuji ${ }^{1,4}$, Asami Yamamoto ${ }^{1,2,4}$, Yoshihiro Takaki ${ }^{3}$, Kenji Ueda ${ }^{2}$, \\ Shinsuke Kawagucci ${ }^{1}$ and Ken Takai ${ }^{1}$ \\ ${ }^{1}$ Subsurface Geobiology Advanced Research (SUGAR) Project, Extremobiosphere Research Program (XBR), \\ Institute of Biogeosciences, Japan Agency for Marine-Earth Science and Technology (JAMSTEC), Yokosuka, \\ Kanagawa, Japan; ${ }^{2}$ Life Science Research Center, College of Bioresource Sciences, Nihon University, \\ Fujisawa, Japan and ${ }^{3}$ Chemosymbiosis System Genomics Team, XBR, Institute of Biogeosciences, \\ JAMSTEC, Yokosuka, Kanagawa, Japan
}

\begin{abstract}
Shinkaia crosnieri is a galatheid crab that predominantly dwells in deep-sea hydrothermal systems in the Okinawa Trough, Japan. In this study, the phylogenetic diversity of active methanotrophs in the epibiotic microbial community on the setae of $S$. crosnieri was characterized by reverse transcription-polymerase chain reaction (RT-PCR) of a functional gene (pmoA) encoding a subunit of particulate methane monooxygenase. Phylogenetic analysis of pmoA transcript sequences revealed that the active epibiotic methanotrophs on S. crosnieri setae consisted of gammaproteobacterial type la and $\mathrm{lb}$ methanotrophs. The effect of different RNA stabilization procedures on the abundance of pmoA and 16S rRNA transcripts in the epibiotic community was estimated by quantitative RT-PCR. Our novel RNA fixation method performed immediately after sampling effectively preserved cellular RNA assemblages, particularly labile mRNA populations, including pmoA mRNA. Methane consumption in live $S$. crosnieri was also estimated by continuous-flow incubation under atmospheric and in situ hydrostatic pressures, and provided a clear evidence of methane oxidation activity of the epibiotic microbial community, which was not significantly affected by hydrostatic pressure. Our study revealed the significant ecological function and nutritional contribution of epibiotic methanotrophs to the predominant $S$. crosnieri populations in the Okinawa Trough deep-sea hydrothermal systems. In conclusion, our study gave clear facts about diversity and methane oxidation of active methanotrophs in the epibiotic community associated with invertebrates.

The ISME Journal (2014) 8, 1020-1031; doi:10.1038/ismej.2013.226; published online 9 January 2014

Subject Category: Microbe-microbe and microbe-host interactions

Keywords: epibiotic community; hydrostatic pressure; in situ fixation; methane oxidation; pmoA
\end{abstract}

\section{Introduction}

Many species of invertebrates that dwell in deep-sea hydrothermal vents are known to host bacteria (epibionts) that adhere to the surface of specialized tissues such as the dorsal setae of the polychaete Alvinella pompejana, the gill chambers of the shrimp Rimicaris exoculata and the setae of the galatheid crabs Shinkaia crosnieri, Kiwa hirsuta and Kiwa puravida (Polz and Cavanaugh, 1995; Cary et al., 1997; Goffredi et al., 2008; Watsuji et al., 2010;

Correspondence: T-o Watsuji, Subsurface Geobiology Advanced Research (SUGAR) Project, Extremobiosphere Research Program (XBR), Institute of Biogeosciences, Japan Agency for Marine-Earth Science and Technology (JAMSTEC), 2-15 Natsushima-cho, Yokosuka, Kanagawa 237-0061, Japan.

E-mail: watsuji@jamstec.go.jp

${ }^{4}$ These authors contributed equally to this work.

Received 24 May 2013; revised 12 November 2013; accepted 17 November 2013; published online 9 January 2014
Thurber et al., 2011). The epibiotic microbial communities associated with these hosts were thought to have chemolithoautotrophic and methanotrophic productivity and to provide continuous nutrition to their hosts (Goffredi et al., 2008; Grzymski et al., 2008; Watsuji et al., 2010; Thurber et al., 2011; Ponsard et al., 2012). The autotrophic productivity of epibiotic communities has been denoted by detection of the activity of key carbon fixation enzymes such as ribulose-1, 5-bisphosphate carboxylase-oxygenase (RuBisCO) (Wirsen et al., 1993), the occurrence and expression of a gene for ATP citrate lyase (Campbell et al., 2003) and the incorporation of ${ }^{13} \mathrm{C}$-labeled bicarbonate into epibiotic cells (Watsuji et al., 2010). Energy metabolism in these epibiotic communities was primarily investigated by analysis of their genomic DNA, leading to the identification of genes with putative functions in energy metabolism (Goffredi et al., 2008; Grzymski et al., 2008; Hugler et al., 
2011). Recently, several studies have determined actual functional activity in the epibiotic communities and combined phylogenetic characterization of epibionts with functional activity (Watsuji et al., 2010, 2012; Ponsard et al., 2012).

Experiments using ${ }^{13} \mathrm{C}$-labeled bicarbonate in the presence of thiosulfate and ferrous iron have found that $R$. exoculata epibionts are capable of chemolithoautotrophic growth by oxidizing reduced sulfur compounds and reduced iron (Ponsard et al., 2012). Tracer experiments, microscopic fluorescence in situ hybridization (FISH) and nanoscale secondary ion mass spectrometry have indicated that epibiotic Sulfurovum cells present on the S. crosnieri setae assimilate inorganic carbon in the presence of thiosulfate (Watsuji et al., 2012), recognizing that these predominant epibionts are thioautotrophs. In contrast, ${ }^{13} \mathrm{C}$-bicarbonate incorporation into $S$. crosnieri epibionts was not enhanced by molecular hydrogen (Watsuji et al., 2010).

The methanotrophic productivity of the epibiotic community on $S$. crosnieri setae has been indicated by the incorporation of ${ }^{13} \mathrm{CH}_{4}$ into the epibionts when dissected setae were incubated with ${ }^{13} \mathrm{CH}_{4}$ as the sole energy and carbon source (Watsuji et al., 2010). In addition, potential methanotrophic epibionts related to the gammaproteobacterial type I methanotrophs were identified as a morphotype of thin short filaments by FISH analysi targeting $16 \mathrm{~S}$ rRNA (Watsuji et al., 2010). These findings point to the possible relevance of gammaproteobacterial type I methanotrophs in the productivity of epibiotic microbial communities, although convincing evidence has not yet been obtained. Recently, epibionts affiliated with type I methanotrophs have also been detected in the gill chamber of $R$. exoculata by FISH, but the methanotrophic productivity in the $R$. exoculata epibionts has not been verified (Guri et al., 2012; Ponsard et al., 2012). Thus, it is still unresolved whether methanotrophic productivity in the epibiotic microbial communities of deep-sea vent invertebrates is driven by the gammaproteobacterial type I methanotrophs or other candidates.

The Iheya North field represents a typical deepsea hydrothermal system in the Okinawa Trough. Its hydrothermal fluid chemistry is highly influenced by the presence of thick terrigenous sediments in the trough basin and is characterized by high concentrations of $\mathrm{CH}_{4}$ and $\mathrm{CO}_{2}$ and a relatively low concentration of iron and molecular hydrogen (Kawagucci et al., 2011). High-temperature vent emissions around enormous hydrothermal mineral deposits provide numerous diffusing hydrothermal fluid flows (Nakagawa et al., 2005a) that support widespread dense colonies of $S$. crosnieri (Watsuji et al., 2010). Among the Okinawa Trough hydrothermal systems examined so far, the Iheya North field has been shown to contain S. crosnieri populations with epibiotic microbial communities that display dual thiotrophic and methanotrophic productivity (Watsuji et al., 2010, 2012). Here we characterized the phylogenetic affiliation of the functionally active methanotrophs present in the epibiotic community of $S$. crosnieri from the Iheya North field. To accomplish this, we examined transcripts of $p m o A$, which encodes a subunit of the particulate methane monooxygenase (pMMO) essential for aerobic methane-oxidizing metabolism and identified active epibiotic methanotrophs based on the deduced PmoA amino-acid sequences. We also estimated methanotrophic activity in the epibiotic community by quantifying the number of pmo $A$ transcripts and by directly measuring methane consumption of $S$. crosnieri individuals under atmospheric and in situ hydrostatic pressure conditions. Moreover, we report that the newly introduced in situ RNA fixation method, which is performed immediately after sampling, effectively preserves epibiotic RNA assemblages, particularly labile mRNA populations.

\section{Materials and methods}

Collection of S. crosnieri from the deep-sea hydrothermal field

S. crosnieri individuals were collected from the Iheya North hydrothermal field in the Okinawa Trough, Japan, during dive no. 1447 on 25 October $2012\left(27^{\circ} 47.44^{\prime} \mathrm{N}, 126^{\circ} 53.80^{\prime} \mathrm{E}\right.$, depth $\left.1001 \mathrm{~m}\right)$ using the JAMSTEC remotely operated vehicle 'HyperDolphin'. Individuals were collected using a suction sampler and stored in a box of chilled seawater attached to remotely operated vehicle. Immediately after onboard recovery, the individuals were washed with sterile artificial seawater. These procedures were performed below $5{ }^{\circ} \mathrm{C}$ because the ambient temperature of $S$. crosnieri in their natural habitats ranges from 4 to $6{ }^{\circ} \mathrm{C}$. Immediately after recovery (within several hours), the methane oxidation activity of three living $S$. crosnieri individuals was measured under in situ hydrostatic (12.0 MPa) and atmospheric pressure (0.1 MPa) (described below).

\section{Fixation}

Several S. crosnieri individuals were collected using another suction sampler from the same colony as that during dive no. 1447 and stored in a 3.5-1 sampling box. After collection at the seafloor, several individuals in the sampling box were immersed in an RNA Stabilization Reagent (RNAlater; Qiagen, Tokyo, Japan) colored in yellow of phenol red filling in the sampling box (in situ fixation). The system consisted of the sampling box, a flexible 6-l plastic bag (Sekisui Chemical, Osaka, Japan) containing $5 \mathrm{l}$ of the fixation solution and a silicon tube ( $\varphi 9 \mathrm{~mm}$; Togawa, Fuchu, Japan) with a valve used to connect the bottom part of the sampling box and the plastic bag. The high-density fixation solution in the flexible bag was poured into the sampling box by lifting the flexible bag above the 
sampling box using a manipulator. When all the seawater in the box containing the $S$. crosnieri individuals had been completely replaced by the fixation solution, the valve was closed and fixation continued. After onboard recovery, the setae were dissected from the fixed S. crosnieri individuals and gently resuspended in the same fixation solution (in situ fixation samples). In addition, the setae samples from $S$. crosnieri individuals collected using the normal suction sampler were dissected and gently suspended in the fixation solution (onboard fixation samples). After the suspensions were preserved at $5{ }^{\circ} \mathrm{C}$ overnight, the harvested setae were stored at $-80^{\circ} \mathrm{C}$ for further analyses. The setae that were not treated with the fixation solution were also dissected and stored at $-80^{\circ} \mathrm{C}$ as a reference (nonfixed samples). These setae samples were derived from $S$. crosnieri individuals with similar carapace lengths of $53-57 \mathrm{~mm}$.

\section{Total RNA preparation}

Total RNA was extracted from the epibiont communities associated with the dissected setae (stored at $-80^{\circ} \mathrm{C}$ ) using the RNA PowerSoil Total RNA Isolation Kit (Mo Bio Laboratories, Carlsbad, CA, USA) according to the manufacturer's instructions. The RNA extract was treated with $0.5 \mathrm{U}$ DNase I (Qiagen) for $10 \mathrm{~min}$ at room temperature to remove any contaminating DNA. The treated RNA was recovered using the RNeasy Mini Kit (Qiagen). The RNA quantity was determined using the Quant-iT RNA Assay Kit (Life Technologies, Tokyo, Japan).

Complementary DNA synthesis and PCR amplification Complementary DNA (cDNA) was synthesized using the High Capacity RNA-to-cDNA Kit (Applied Biosystems, Tokyo, Japan) according to the accompanying instruction manual. In total, $200 \mathrm{ng}$ of the extracted total RNA was used as a template for reverse transcription, and the mixture was stored at $-20^{\circ} \mathrm{C}$ for subsequent PCR amplification. To verify the absence of DNA contamination of the RNA extracts, control reactions were prepared without reverse transcriptase. PCR amplifications were performed in $50-\mu \mathrm{l}$ (total volume) volumes in $0.3-\mathrm{ml}$ tubes. Each PCR mixture consisted of $1 \times$ PCR buffer (Takara, Otsu, Japan), 200 mm of each dNTP (Takara), $400 \mathrm{~nm}$ each of forward and reverse primers, $0.05 \%$ $\left(\mathrm{w} \mathrm{v}^{-1}\right)$ bovine serum albumin (Sigma-Aldrich, Tokyo, Japan), $2.5 \mathrm{U}$ of Taq DNA polymerase (Takara) and $10 \mathrm{ng}$ of cDNA from the epibiotic community fixed in situ. A partial fragment of pmoA was amplified with the primers A189f/ mb661r (Costello and Lidstrom, 1999) and primers A189f/A682r (Holmes et al., 1995). The amplification was performed with an initial denaturation step at $94{ }^{\circ} \mathrm{C}$ for $2 \mathrm{~min}$, followed by 30 cycles at $94{ }^{\circ} \mathrm{C}$ for $1 \mathrm{~min}$, at different annealing temperatures as required for $1 \mathrm{~min}$ and at $72^{\circ} \mathrm{C}$ for $1 \mathrm{~min}$, with a final extension step at $72{ }^{\circ} \mathrm{C}$ for $5 \mathrm{~min}$. The annealing temperature was $55^{\circ} \mathrm{C}$ for primers A189f/mb661r (Dumont et al., 2011) and $56^{\circ} \mathrm{C}$ for primers A189f/ A682r (Holmes et al., 1995).

Quantitative PCR for pmoA mRNA and $16 S$ rRNA Quantitative PCR (qPCR) of $p m o A$ was performed using the 7500 Real-Time PCR System (Applied Biosystems). All data analyses were performed with 500 System SDS software (version 1.4.0.25; Applied Biosystems). A partial fragment of $p m o A$ was amplified with the primers A189f/mb661r. The reaction mixture contained $1 \times$ Platinum SYBER Green SuperMix (Invitrogen, Tokyo, Japan), $1 \times$ ROX, $400 \mathrm{~nm}$ of each primer, $0.05 \%\left(\mathrm{wv}^{-1}\right)$ bovine serum albumin, $1 \mathrm{~mm} \mathrm{MgCl}_{2}, 10 \mathrm{ng}$ of cDNA and double-distilled $\mathrm{H}_{2} \mathrm{O}$ to a final volume of $50 \mu \mathrm{l}$. Reactions for each sample were performed in triplicate. The plasmid DNA cloning a $p m o A$ cDNA sequence ihePR661_206, which was amplified by primers A189f/mb661r, was used as a qPCR standard. The $p m o A$ cDNA sequence cloned into the pCR2.1-TOPO vector (Invitrogen) was purified with a Plasmid Mini Kit (Qiagen). The recombinant plasmid DNA was quantified by Quant-iT dsDNA BR Assay Kit (Life Technologies). An external standard curve was generated with serial dilutions of the plasmid DNA ranging from $1.0 \times 10^{2}$ to $1.0 \times 10^{7}$ copy number of the pmoA cDNA/reaction. The amount of total RNA extracted from all setae of a $S$. crosnieri individual should be equivalent to that of total RNA of an epibiotic population of a $S$. crosnieri individual, although the amount will depend on extraction efficiency. Because total RNA of epibiotic communities was obtained by total RNA extraction from all setae of a $S$. crosnieri individual, quantification of the $p m o A$ cDNA was normalized as the abundance of $p m o A$ mRNA per epibiotic population of a $S$. crosnieri individual, which was estimated using the external standard curve and the amount of total RNA extracted from all setae of a $S$. crosnieri individual. The qPCR of $p m o A$ was performed with an initial denaturation step at $94^{\circ} \mathrm{C}$ for $4 \mathrm{~min}$, followed by 40 cycles of denaturation at $94{ }^{\circ} \mathrm{C}$ for $1 \mathrm{~min}$, annealing at $55^{\circ} \mathrm{C}$ for $1 \mathrm{~min}$ and extension at $72{ }^{\circ} \mathrm{C}$ for $1 \mathrm{~min}$. Fluorescence data were acquired during the extension procedure. The qPCR of whole microbial 16S rRNA using the cDNA libraries was performed as described previously (Takai and Horikoshi, 2000). Abundance of $16 \mathrm{~S}$ rRNA per epibiotic population of a $S$. crosnieri individual was also estimated using external standard curve and the amount of total RNA extracted from all setae of a $S$. crosnieri individual.

\section{Sequencing and phylogenetic analysis}

The RT-PCR-amplified products of pmoA mRNA were sequenced as described previously (Watsuji et al., 2010). The sequences were determined on 
both strands. The partial PmoA amino-acid sequences deduced from the cDNA sequences were compared first among all the PmoA amino-acid sequences obtained from the $S$. crosnieri epibiont cDNA libraries tentatively to identify the representative PmoA sequences (showing $>97-99 \%$ aminoacid sequence similarity), and then were compared with the similar sequences in public databases by BLAST searches. The resulting sequences were manually aligned with similar sequences downloaded from the public databases, and the phylogenetic relationships were analyzed using ARB software package (Ludwig et al., 2004). The aligned sequence length for the PmoA amino-acid sequences was 157 residues. Distance matrix trees were constructed by the neighbor-joining method (Saitou and Nei, 1987), and the topology of the trees was evaluated by bootstrapping with 1000 resamplings (Felsenstein, 1985). Phylogenetic trees using the PmoA amino-acid sequences were also reconstructed by Bayesian method using the program MrBayes v.3.1.2 (Huelsenbeck and Ronquist, 2001; Ronquist and Huelsenbeck, 2003). The analysis was conducted as six chains for one million generations. Sample frequencies were 100 generations, and the burn-in was the first 2500 samples.

\section{Methane oxidation activity of live S. crosnieri}

Methane oxidation of epibionts associated with $S$. crosnieri individuals under in situ hydrostatic pressure was examined using a previously described high-pressure continuous-flow incubation apparatus (Watsuji et al., 2012). This ensured a continuous supply of a certain concentration of dissolved methane and oxygen to a live $S$. crosnieri individual confined to a glass cylinder (Watsuji et al., 2012) under a hydrostatic pressure of 12.0 MPa. On the other hand, the methane oxidation of $S$. crosnieri individuals under atmospheric hydrostatic pressure was examined using a continuous-flow apparatus that incubated a live $S$. crosnieri individual in the same glass incubation vessel but under a hydrostatic pressure of $0.1 \mathrm{MPa}$ and with a continuous supply of similar concentrations of dissolved methane and oxygen. The continuous-flow apparatus comprised a peristaltic pump (MasterFlex L/S model 7524-50, pump head model 7518-10; Cole-Parmer Instrument Co., Vernon Hills, IL, USA) and glass incubation vessels (Horiguchi Ironworks Co., Kobe, Japan) directly connected to hydraulic tubes for transporting the liquid supplied by the peristaltic pump. All the hydraulic tubing used for transporting the liquid was manufactured using MasterFlex silicone tubing (Cole-Parmer Instrument Co.; size 25).

Three S. crosnieri individuals were used to measure methane oxidation under hydrostatic pressures of both 0.1 and $12.0 \mathrm{MPa}$, with the first measurement being made under $0.1 \mathrm{MPa}$ and the next under 12.0 MPa. Each individual was incubated at $5{ }^{\circ} \mathrm{C}$ in a glass cylinder filled with artificial seawater $\left(25 \mathrm{gl}^{-1} \mathrm{NaCl}, 4.2 \mathrm{gl}^{-1} \quad \mathrm{MgCl}_{2} \cdot 6 \mathrm{H}_{2} \mathrm{O}\right.$, $3.4 \mathrm{gl}^{-1} \quad \mathrm{MgSO}_{4} \cdot 7 \mathrm{H}_{2} \mathrm{O}, \quad 0.5 \mathrm{gl}^{-1} \mathrm{KCl}, 0.7 \mathrm{gl}^{-1}$ $\mathrm{CaCl}_{2} \cdot 2 \mathrm{H}_{2} \mathrm{O}, 14 \mathrm{mg} \mathrm{l}^{-1} \quad \mathrm{~K}_{2} \mathrm{HPO}_{4}$; adjusted to $\mathrm{pH}$ 6.8) filtered using a $0.22-\mu \mathrm{m}$-pore membrane under air. All the artificial seawater contained dissolved methane at a final concentration of approximately $20 \mu \mathrm{M}$. The dissolved methane was manufactured as follows: $2.5 \mathrm{ml}$ of methane was added to $1 \mathrm{l}$ of artificial seawater in a 1150-ml glass bottle (Duran, Berlin, Germany) sealed with a butyl rubber stopper, and this was incubated at $5{ }^{\circ} \mathrm{C}$ for 2 days to equilibrate the methane gas. In the experiment, the artificial seawater was supplied at a flow rate of $3 \mathrm{ml} \mathrm{min}{ }^{-1}$ for $70 \mathrm{~min}$ at $5{ }^{\circ} \mathrm{C}$ under a hydrostatic pressure of 0.1 or $12.0 \mathrm{MPa}$. Pressurization to 12.0 MPa took 1-2 min. Thereafter, $5 \mathrm{ml}$ of influent and effluent seawater was sampled by syringe at 5-min intervals during incubation. These samples were then injected into a 69-ml vacuum vial (V-50; Nichiden-Rika Glass Co., Kobe, Japan) with a butyl rubber stopper and frozen at $-20^{\circ} \mathrm{C}$. At the onshore laboratory, the vacuum-extracted methane in the vial was assayed on a gas chromatograph (GC-4000; GL Science, Tokyo, Japan) with a pulsed discharge detector and a column packed with Molecular Sieve. The wet weight of the three specimens (specimens 1, 2 and 3) used for measuring methane oxidation was 12.5, 14.2 and 10.4 g, respectively. The dry weight of the setae from the three specimens (specimens 1, 2 and 3) was 73.4, 57.3 and $59.0 \mathrm{mg}$, respectively.

\section{Results and discussion}

There are two known forms of methane monooxygenases: soluble methane monooxygenase and pMMO. Soluble methane monooxygenase is found only in certain methanotrophs and typically expressed only under low-copper conditions (Murrell et al., 2000). In contrast, pMMO is found in all known methanotrophs, except in species of the genus Methylocella (Dedysh et al., 2000). Thus, pmoA, which encodes the transmembrane subunit of pMMO, is an established molecular marker of methanotrophic activity potential. In fact, the occurrence of $p m o A$ has been identified in the epibiotic community of $R$. exoculata (Zbinden et al., 2008). FISH analysis targeting $16 \mathrm{~S}$ rRNA also detected cells phylogenetically related to type I methanotrophs in the epibiotic communities associated with $S$. crosnieri and $R$. exoculata (Watsuji et al., 2010; Guri et al., 2012), although sulfur- and iron-oxidizing autotrophic productivity was suggested by ${ }^{13} \mathrm{C}$-tracer assimilation experiments in $R$. exoculata epibionts (Ponsard et al., 2012). The detection of functional genes in DNA assemblages isolated from an epibiotic community does not necessarily indicate that the encoded function is operative because DNA can be stable in dormant and dead cell populations (Lindahl, 1993). Furthermore, the detection of $16 \mathrm{~S}$ rRNA gene sequences closely 
related to gammaproteobacterial type I methanotrophs and the 16S rRNA-targeting FISH analyses do not ensure the presence of methanotrophic activity. An adequate level of certainty requires the combined use of nanoscale secondary ion mass spectrometry or stable isotope probing to specify the cellular level of uptake of labeled $\mathrm{CH}_{4}$ (Hery et al., 2008; Watsuji et al., 2012).

In this study, uncloned cDNA libraries were constructed from total RNA extracted from epibiotic communities associated with three $S$. crosnieri individuals fixed in situ. Because none of the PCR products derived from $p m o A$ transcripts was obtained from cDNA libraries prepared without reverse transcriptase, it was confirmed that the amplified $p m o A$ genes do not originate from contaminating genomic DNA. A total of $138 \mathrm{pmoA}$ cDNA clones amplified using two primer sets were sequenced, and 18 representative PmoA amino-acid sequences were identified (Table 1). This report describes the first detection of $p m o A$ transcripts in RNA assemblages extracted from the epibiotic community associated with a deep-sea vent invertebrate, $S$. crosnieri, by RT-PCR. The RT-PCR amplification of $p m o A$ transcripts is more tightly coupled with methane-oxidizing metabolism in functionally active methanotrophic populations owing to the susceptibility of RNA to degradation in inactive cells. This along with results from previous studies

Table 1 Composition of representative reverse-transcribed pmoA clones in the epibiotic community associated with $S$. crosnieri

\begin{tabular}{lccc}
\hline $\begin{array}{l}\text { Group represent } \\
\text { ID }\end{array}$ & $\begin{array}{c}\text { INSD } \\
\text { accession } \\
\text { no. }\end{array}$ & $\begin{array}{c}\text { Number of } \\
\text { clones }\end{array}$ & $\begin{array}{c}\text { PmoA sequence } \\
\text { identity (\%) } \\
\text { among each } \\
\text { other }\end{array}$ \\
\cline { 3 - 4 } & & $\begin{array}{c}\text { A189/ A189/ } \\
\text { mb661r A682r }\end{array}$ & \\
& & &
\end{tabular}

Type Ia

$\begin{array}{llrrc}\text { ihePR682_243 } & \text { AB794881 } & 3 & 4 & 98-100 \\ \text { ihePR682_350 } & \text { AB794882 } & 34 & 28 & 97-100 \\ \text { ihePR661_145 } & \text { AB794867 } & 1 & 1 & 99 \\ \text { ihePR682_216 } & \text { AB794870 } & 0 & 1 & - \\ \text { ihePR682_157 } & \text { AB794879 } & 0 & 1 & - \\ & & & & \\ \text { ihePR661_313 } & \text { AB794873 } & 2 & 1 & 99-100 \\ \text { ihePR682_112 } & \text { AB794874 } & 2 & 8 & 99-100 \\ \text { ihePR661_111 } & \text { AB794866 } & 15 & 6 & 99-100 \\ \text { ihePR661_218 } & \text { AB794871 } & 1 & 0 & - \\ \text { ihePR682_135 } & \text { AB794876 } & 6 & 6 & 97-100 \\ \text { ihePR682_364 } & \text { AB794883 } & 3 & 1 & 99-100 \\ & & & & 99-100 \\ \text { ihePR661_206 } & \text { AB794868 } & 4 & 1 & - \\ \text { ihePR661_215 } & \text { AB794869 } & 1 & 0 & - \\ \text { ihePR661_216 } & \text { AB794870 } & 1 & 0 & - \\ \text { ihePR661_222 } & \text { AB794872 } & 1 & 0 & \\ & & & & - \\ \text { Ib } & & & & \\ \text { hePR682_134 } & \text { AB794875 } & 0 & 4 & 100 \\ \text { hePR682_147 } & \text { AB794878 } & 0 & 1 & - \\ \text { hePR682_136 } & \text { AB794877 } & 0 & 1 & \end{array}$

Abbreviation: INSD, International Nucleotide Sequence Databases. strengthens the presumption that there is a significant population of functionally active methanotrophs in these epibiotic communities.

Next, the representative sequences were subjected to phylogenetic analysis (Table 1). It has been pointed out that the phylogenetic relationship of PmoA amino-acid sequences deduced from pmoA sequences is congruent with the phylogeny based on 16S rRNA gene sequences (Heyer et al., 2002; Kolb et al., 2003). It has also been accepted that the characterization of $p m o A$ transcripts can be an important molecular tool for assessing the diversity of active methanotrophic communities in various habitats (Chen et al., 2008). All the PmoA aminoacid sequences identified in the RNA assemblages from epibiotic communities were classified as gammaproteobacterial type I methanotrophs. They were further divided into type Ia and type Ib subgroups of methanotrophs in the phylogenetic trees using neighbor-joining and Bayesian methods (Figure 1 and Supplementary Information). The PmoA amino-acid sequences identified as type Ia and $\mathrm{Ib}$ methanotrophs, using the neighbor-joining method, showed similar patterns using the Bayesian method (Figure 1 and Supplementary Information). Therefore, the active epibiotic methanotrophs were composed mainly of type Ia and Ib methanotrophs, although a larger number of sequencing analyses may reveal a greater diversity of PmoA sequences, and therefore active methanotrophs, in the epibiotic communities of $S$. crosnieri. In addition, $S$. crosnieri has been nutritionally supported by methanotrophic production from methanotrophs associated with the host animal, and the host-associated methanotrophs have been regarded as active epibiotic methanotrophs contributing to methanotrophic productivity, because ${ }^{13} \mathrm{C}$-methane tracer experiment using live $S$. crosnieri revealed that the labeled methane was incorporated into host $S$. crosnieri as well as its epibionts (Watsuji et al., 2010). Thus, the results of our previous and present studies suggested that the active type Ia and Ib methanotrophs in the epibiotic community could have a significant role in the nutrition of $S$. crosnieri, although a potential contribution of other methanotrophs was not completely excluded (Watsuji et al., 2010).

Most of the epibiotic PmoA sequences affiliated with the type Ia methanotrophic PmoA, except for ihePR661_222 and ihePR682_216, shared $>93 \%$ sequence similarity with the PmoA sequence of the Methylococcaceae bacterium isolate SF-BR (Figure 1). It has been pointed out that similarity of 93\% in PmoA amino-acid sequence corresponds to that of $97 \%$ in $16 \mathrm{~S}$ rRNA gene sequence (Degelmann et al., 2010). The microbiological characteristics of the methanotrophic strain SF-BR are completely unknown and only the pmoA and 16S rRNA gene sequences have been deposited in public databases. In our previous study, phylogenetic analysis of $16 \mathrm{~S}$ rRNA gene sequences obtained from DNA extracts of $S$. crosnieri epibiotic communities revealed that 


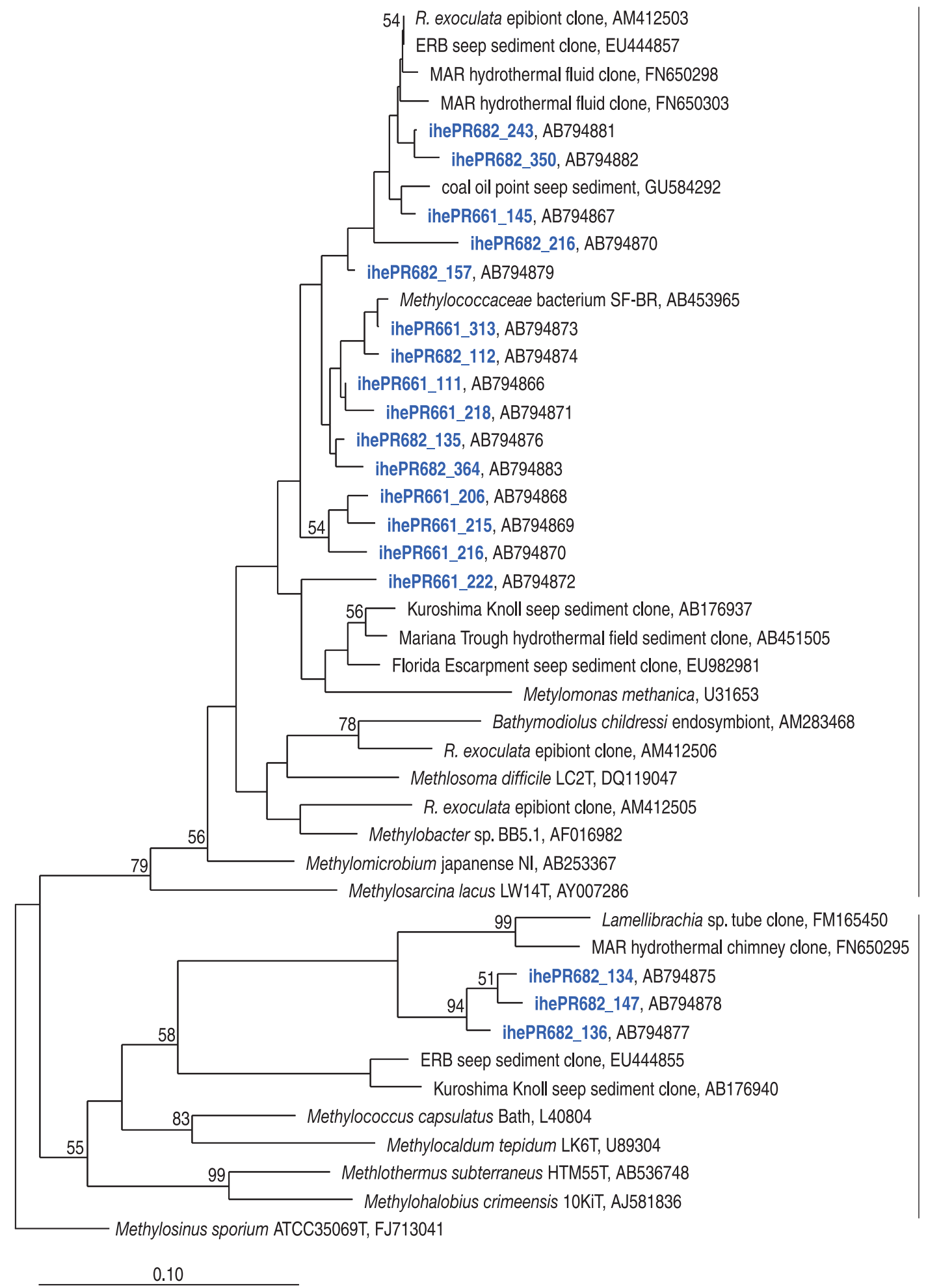

Figure 1 Phylogenetic tree based on the partial amino-acid sequences of the pMMO subunit A, deduced from the $p m o A$ transcript sequences. The tree was constructed by neighbor-joining analysis using 157 amino-acid residues. Sequences obtained from the epibiotic community on $S$. crosnieri are shown in colored letters. Bootstrap analysis was performed with 1000 resampled data sets. Bootstrap values $>50 \%$ are shown at branch points. Scale bar indicates 0.1 substitutions per site.

only two 16S rRNA gene sequences (defined with a $>97 \%$ similarity threshold in $16 \mathrm{~S}$ rRNA gene sequence) were related to the gammaproteobacterial type Ia methanotrophs and that the one sequence,
IHE0 1191 (accession no. AB476240), was the most abundant ribotype in this group (Watsuji et al., 2010). This $16 \mathrm{~S}$ rRNA gene sequence also had $97 \%$ similarity with the 16S rRNA gene sequence of the 
strain SF-BR (Watsuji et al., 2010). Because both the abundant 16S rRNA gene (e.g., IHE0_1191) (Watsuji et al., 2010) and the $p m o A$ transcript sequences in the epibiotic community are closely related to the $16 S$ rRNA and $p m o A$ gene sequences of the strain SF-BR, these sequences could be derived from genetically similar epibionts. Previous microscopic FISH analysis targeting type Ia methanotrophic $16 \mathrm{~S}$ rRNA, including sequence IHE0_1191, indicated the abundance of potentially viable type Ia methanotrophic cells in the epibiotic community (Watsuji et al., 2010). RT-PCR amplification of pmoA mRNA probably confirmed the presence of active epibiotic type Ia methanotrophs in this study. These results strongly suggest that the methanotrophic productivity of the $S$. crosnieri epibiotic community is, in a large part, sustained by the methane oxidation of type Ia methanotrophs closely related to strain SFBR. To validate the substantial contribution of the type Ia methanotrophs closely related to strain SF$\mathrm{BR}$ to methanotrophic productivity, FISH analyses specifically targeting both their $16 \mathrm{~S}$ rRNA and pmoA mRNA will be conducted for the $S$. crosnieri epibiotic community, similar to previous experiments on the role of methanotrophic endosymbionts in the gills of vent mussels (Wendeberg et al., 2012). In addition, the substantial contribution to methanotrophic productivity made by potentially abundant methanotrophic populations will be further substantiated by a combination of FISH analysis targeting the $16 \mathrm{~S}$ rRNA sequences and incorporation of ${ }^{13} \mathrm{C}$-labeled methane by nanoscale secondary ion mass spectrometry or ${ }^{14} \mathrm{C}$-labeled methane using microscopic autoradiography.

The epibiotic PmoA sequences classified as type Ib methanotrophic PmoA were not closely related to any of the previously known PmoA sequences but were phylogenetically associated with sequences from the tube-adhesive microbial community of the tubeworm Lamellibrachia sp. (90-91\% sequence similarity) (Figure 1). In our previous study, transmission electron microscopic observation of the epibiotic community on an $S$. crosnieri individual from the Iheya North field revealed the presence of two different morphotypes (short filaments and rods) of cells. These morphotypes represent an evident intracytoplasmic membrane structure (Watsuji et al., 2010) known as a typical morphological characteristic of type I methanotrophs (Jensen and Corpe, 1991; Heyer et al., 2005). Microscopic FISH analysis specific to the $16 \mathrm{~S}$ rRNA of the type Ia methanotrophs only revealed a short filament morphotype (Watsuji et al., 2010). It seems likely that the epibiotic type Ib methanotrophs identified through the sequencing of $p m o A$ transcripts may be rod-shaped morphotypes with an intracytoplasmic membrane structure, although FISH analysis specific to the $p m o A$ mRNA of the type $\mathrm{Ib}$ methanotroph will be needed to determine the morphology of the epibiotic type Ib methanotrophic cells.

The abundance of $p m o A$ transcripts in the total RNA assemblages retrieved from the epibiotic communities of three $S$. crosnieri individuals fixed in situ was estimated by RT-qPCR using the primer set A189f/mb661r. We also compared the abundance of pmoA mRNA and 16S rRNA in the epibiotic communities of three $S$. crosnieri individuals collected using different sampling procedures (in situ fixation, onboard fixation and nonfixed samples). In each of the fixation procedures, the epibiont RNA assemblages from three host individuals were used for the quantification of the abundance of $p m o A$ mRNA and $16 S$ rRNA. RT-qPCR quantification was performed in triplicate for each epibiont RNA assemblage from each individual. The standard errors of the RT-qPCR quantifications were estimated to be within $4.1 \%$ and $7.7 \%$ of the average amounts of pmoA mRNA and 16S rRNA, respectively. The mean and standard deviation values obtained from the epibiont RNA assemblages from three host individuals are shown in Figure 2a.
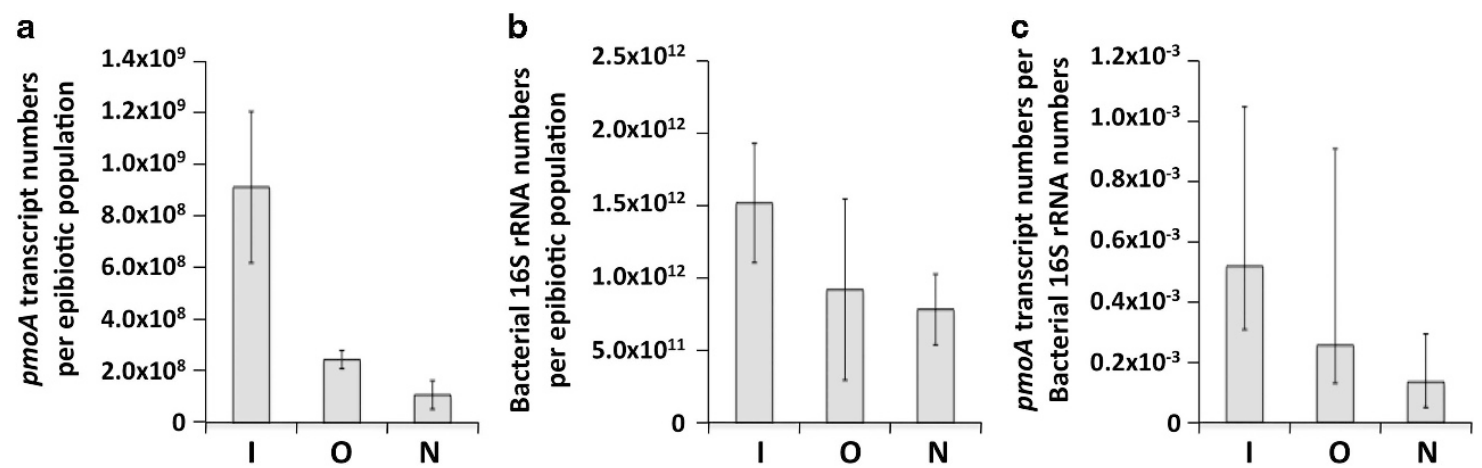

Figure 2 The number of $p m o A$ transcripts and 16S rRNAs quantified by RT-qPCR using RNA extracted from the epibiotic communities on $S$. crosnieri individuals by different sampling procedures. (a) The abundance of $p m o A$ transcripts per epibiotic population of a S. crosnieri individual. (b) The abundance of bacterial $16 \mathrm{~S}$ rRNA per epibiotic population of a $S$. crosnieri individual. (c) The abundance (copy number) ratio of pmoA transcripts and 16S rRNA in the epibiotic population of a $S$. crosnieri individual. I indicates the in situ fixation samples, $\mathrm{O}$ indicates the onboard fixation samples and $\mathrm{N}$ indicates the nonfixed samples. Three different $S$. crosnieri individuals were assessed for each process, and the data are expressed as the mean \pm s.d. 
The most abundant pmoA mRNA was obtained from the epibiotic communities on $S$. crosnieri individuals fixed in situ. On average, $9.5 \times 10^{8}$ copies per epibiotic population of a $S$. crosnieri individual were estimated by the abundance of pmoA mRNA in total RNA extracted from all setae of a $S$. crosnieri individual (Figure 2a). The amounts of $p m o A$ mRNA obtained from the epibiotic communities using onboard fixation and no fixation were $2.6 \times 10^{8}$ and $1.1 \times 10^{8}$ copies per epibiotic population of a $S$. crosnieri individual, respectively (Figure 2a). Thus, the relative abundance of pmoA transcripts in the epibiotic community fixed in situ was 3.7- and 8.6-fold higher than that of the community sampled by onboard fixation and no fixation, respectively, and these differences were statistically significant (unpaired $t$-test, $P<0.05$ ) (Figure 2a). In general, fixation timing after sampling of a planktonic microbial community in the in situ habitat is critical for determining the abundance and pattern of in situ cellular gene expression (Frias-Lopez et al., 2008). The relatively greater abundance of $p m o A$ mRNA in the epibiotic community fixed in situ clearly indicates the effective stabilization of labile mRNA in the epibiotic cells by the addition of the fixative immediately after sampling. Using the remotely operated vehicle, the recovery and sampling of $S$. crosnieri individuals from their deep-sea colonies in the Iheya North field (the water depth is approximately $1000 \mathrm{~m}$ ) required at least $2 \mathrm{~h}$. In addition, the recovery from the deep-sea colonies and the transfer to the onboard laboratory was accompanied by a drastic change in the physical and chemical conditions of the seawater in the sampling box for the $S$. crosnieri individuals as well as their epibionts. The drastic environmental changes could be inhi bitory and even lethal and lead to the degradation of labile mRNA, including the $p m o A$ transcripts in the epibiont cells. Indeed, it has been demonstrated that the abundance of a subunit of ammonia monooxygenase gene $(a m o A)$ transcripts in the planktonic microbial community of the central Baltic Sea (70-120 m depth) fixed in situ was 6- to 30 -fold higher than that in the planktonic microbial community that was not treated with a fixative (Feike et al., 2012).

We also estimated the abundance of whole bacterial $16 \mathrm{~S}$ rRNA in the epibiotic community by RT-qPCR analysis. As observed with the pmoA mRNA, the most abundant 16S rRNA was obtained from the epibiotic community on $S$. crosnieri individuals fixed in situ (Figure 2b). In the case of 16S rRNA, the difference in abundance among the various fixation procedures was not statistically significant (unpaired $t$-test, $P>0.05$ ). However, the abundance (copy number) ratio of $p m o A$ mRNA and whole bacterial 16S rRNA in the epibiotic population of a $S$. crosnieri individual was significantly influenced by the presence or absence of the RNA fixation procedure and the timing of fixation after the sampling (Figure 2c). The ratios were $5.4 \times 10^{-4}$ in the in situ fixation samples, $2.7 \times 10^{-4}$ in the samples fixed onboard and $1.4 \times 10^{-4}$ in the nonfixed samples, respectively (Figure 2c). These results strongly suggest that the pmoA mRNA in the epibiotic community degrades faster than the whole bacterial $16 \mathrm{~S}$ rRNA. It has been reported that the 16S rRNA abundance of planktonic microbial communities is not significantly influenced by different fixation processes (Deutscher, 2006; Feike et al., 2012). Thus, our quantitative data with epibiotic pmoA mRNA and whole bacterial 16S rRNA may result from differences in degradation susceptibility between mRNA (for methanotroph pmoA) and rRNA (for the whole epibiotic bacteria $16 \mathrm{~S}$ rRNA). Otherwise, some specific bacterial populations, in this case gammaproteobacterial type I methanotrophs, may be more sensitive to the environmental changes during sampling and recovery, and thus both the pmoA mRNA and 16S rRNA of type I methanotrophs may degrade faster than those of other predominant epibiotic populations. These possible explanations will be clarified by future quantitative metatranscriptomic analysis (a number of sequence analysis) of RNA assemblages, including whole bacterial rRNAs and mRNAs obtained from the epibiotic communities of three $S$. crosnieri individuals under the different fixation procedures. Nevertheless, our quantitative data clearly demonstrate the necessity of using the in situ fixation procedure for subsequent transcriptomic analysis of epibiotic communities associated with deep-sea vent invertebrates in their natural environments. In addition, epibiotic metatranscriptomics will become more important to understand actual functional activities because functional gene analyses of epibiotic communities associated with $R$. exoculata, A. pompejana and Kiwa hirsuta have already been performed (Goffredi et al., 2008; Grzymski et al., 2008; Hugler et al., 2011).

Methane oxidation activity was estimated using the same three $S$. crosnieri individuals under both atmospheric and elevated hydrostatic pressures via a continuous-flow incubation of dissolved methane and oxygen (Table 2). We confirmed the viability of the $S$. crosnieri individuals throughout the atmospheric and in situ pressure incubation experiments by visual observation of their movement and behaviors. A relative decrease in the dissolved methane concentration of the effluent seawater compared with that of the influent seawater was also detected in the negative control experiments where no $S$. crosnieri individual was present. This was probably due to the diffusion of methane gas through the silicone tube and the formation of methane gas bubbles in the flow lines (Table 2). However, much greater methane consumption rates were obtained from the experiments with a living $S$. crosnieri individual (Table 2). The net methane consumption rates were quite similar between the experiments under atmospheric and in situ 
Table 2 Net methane consumption rates of live S. crosnieri individuals at hydrostatic pressures of 0.1 and $12.0 \mathrm{MPa}$ during continuousflow incubation

\begin{tabular}{|c|c|c|c|c|c|c|}
\hline \multirow[t]{2}{*}{$\begin{array}{l}\text { Specimen } n \\
\text { no. }\end{array}$} & \multirow[t]{2}{*}{$\begin{array}{l}\text { Pressure } \\
\text { (MPa) }\end{array}$} & \multicolumn{2}{|c|}{$\begin{array}{l}\text { Methane consumption rate } \\
\qquad\left(\mu \mathrm{mol} h^{-1}\right)\end{array}$} & \multicolumn{3}{|c|}{ Net methane consumption rate } \\
\hline & & $\begin{array}{c}\text { With } \\
\text { individual }^{a}\end{array}$ & $\begin{array}{c}\text { Without } \\
\text { individual }^{a}\end{array}$ & $\begin{array}{l}\text { (umol } h^{-1} \text { per } \\
\quad \text { individual) }\end{array}$ & $\begin{array}{l}\text { ( } \mu \mathrm{molh}^{-1} \mathrm{~g}^{-1} \text { of wet } \\
\text { individual) }\end{array}$ & $\begin{array}{c}\left(\mu \mathrm{mol} h^{-1} g^{-1} \text { of }\right. \\
\text { setae })\end{array}$ \\
\hline \multirow[t]{2}{*}{1} & 0.1 & $3.12 \pm 0.10$ & 1.01 & $2.11 \pm 0.10$ & $0.17 \pm 0.008$ & $28.7 \pm 1.4$ \\
\hline & 12.0 & $2.24 \pm 0.16$ & 0.22 & $2.02 \pm 0.16$ & $0.16 \pm 0.013$ & $27.5 \pm 2.2$ \\
\hline \multirow[t]{2}{*}{2} & 0.1 & $2.46 \pm 0.13$ & 1.01 & $1.45 \pm 0.13$ & $0.10 \pm 0.009$ & $25.3 \pm 2.3$ \\
\hline & 12.0 & $1.86 \pm 0.01$ & 0.22 & $1.64 \pm 0.01$ & $0.12 \pm 0.001$ & $28.6 \pm 0.2$ \\
\hline \multirow[t]{2}{*}{3} & 0.1 & $2.64 \pm 0.36$ & 1.01 & $1.63 \pm 0.36$ & $0.16 \pm 0.035$ & $27.6 \pm 6.1$ \\
\hline & 12.0 & $1.84 \pm 0.09$ & 0.22 & $1.62 \pm 0.09$ & $0.16 \pm 0.009$ & $27.5 \pm 1.5$ \\
\hline
\end{tabular}

${ }^{a}$ All methane consumption rates were measured at 5-min intervals during incubation and determined using steady-state data. They are expressed as the mean \pm s.d.

hydrostatic pressure (Table 2), and no statistically significant differences between the independent experiments were observed, although these used three different specimens (unpaired $t$-test, $P>0.05$ ).

It has been suggested that $S$. crosnieri ingest the epibionts because of frequently observed behaviors in situ and when reared in the laboratory. S. crosnieri comb out setae that are densely covered with epibionts using their third maxillipeds and bring the maxilliped to their mouths (Watsuji et al., 2010). As feeding of epibionts could affect the activity measurements, the potential feeding behaviors were visually observed during the experiments. The behaviors did barely occur during the incubation time of $70 \mathrm{~min}$. In addition, even if the epibionts were frequently ingested by the potential feeding behaviors, the extant biomass of the epibiotic community was much larger than the amount ingested by the host $S$. crosnieri, and the reproduction rate of the epibiotic community was probably higher than the ingestion rate of the host S. crosnieri. Thus, the potential feeding behaviors of the host individuals seem to have little effect on the metabolic activity of the epibionts during the experiments, such as the sulfur oxidation activity in the previous study (Watsuji et al., 2012) and even the methane oxidation activity in this study.

The methane oxidation activities of epibiotic methanotrophic populations under atmospheric pressure have been previously measured using the shell surface of a limpet (Lepetodrilus fucensis) and the tube of a tubeworm (Ridgeia sp.) from deep-sea hydrothermal vent fields (de Angelis et al., 1991b). The methane oxidation rate of the $S$. crosnieri individuals studied here was more than 30000 times higher than that of the epibionts on these animal tissues $\left(0.0551 \mathrm{nmolh}^{-1}\right.$ per L. fucensis shell and $0.0033 \mathrm{nmol} \mathrm{h}^{-1}$ per tube of Ridgeia sp.). The much greater methane oxidation potential of S. crosnieri is likely consistent with the nutritional significance of epibiotic methanotrophic productivity to the host $S$. crosnieri individuals, as suggested previously (Watsuji et al., 2010). The methane oxidation activity of a cold seep mussel (Bathymodiolus sp.) that contains a gammaproteobacterial type I methanotroph as an endosymbiont has been measured at a hydrostatic pressure of $0.54 \mathrm{MPa}$ (Kochevar et al., 1992). The methane oxidation rates per unit (1 $\mathrm{g}$ wet-individual weight) of $S$. crosnieri individuals were two- to sixfold lower than the rates per unit (1 g shell-free wet-individual weight) of Bathymodiolus sp. individuals at the same dissolved methane concentration of $20 \mu \mathrm{M}$, and at similar temperatures $\left(5^{\circ} \mathrm{C}\right.$ in this study and $6{ }^{\circ} \mathrm{C}$ in the previous study) (Kochevar et al., 1992). The comparison may simply reveal that the average methane oxidation rate of a $S$. crosnieri individual is lower than that of a cold seep Bathymodiolus sp. and its endosymbionts. However, the methane oxidation rates of cold seep Bathymodiolus sp. individuals are standardized by the shell-free wet weights, and the cold seep Bathymodiolus sp. has only the single phylogenetic group of methanotroph as the endosymbiont, as opposed to the heterologous phylogenetic and metabolic compositions of the $S$. crosnieri epibionts (Kochevar et al., 1992). Thus, the comparison may not simply be interpreted as a result of different methane oxidation rates per individual between $S$. crosnieri and the cold seep Bathymodiolus sp. Rather, it may be an important finding that the methane oxidation rates per individual between the $S$. crosnieri and the cold seep Bathymodiolus sp. are within the same order of magnitude.

The methane oxidation rates of the three different individuals were not statistically significantly different when the experiments were performed under in situ hydrostatic and atmospheric pressure. Indeed, the net methane consumption rates per an amount of setae were very similar (Table 2), and the differences among the six values were not statistically significant (unpaired $t$-test, $P>0.05$ ). These results indicate that the methane oxidation activity of $S$. crosnieri individuals is dependent on the 
amount of setae, that is, the biomass of the epibiotic community and that the epibiotic methaneoxidizing function is not significantly affected by hydrostatic pressure. Using the planktonic microbial communities in the hydrothermal plume and the ambient deep-sea waters at the Endeavor segment field of the Juan de Fuca Ridge, de Angelis et al. (1991a) demonstrated that ${ }^{14} \mathrm{CH}_{4}$ incorporation into microbial cells was elevated under in situ hydrostatic pressure (21-62\%) compared with that under atmospheric pressure. Because this study estimated ${ }^{14} \mathrm{CH}_{4}$ assimilation into cellular compounds but not methane oxidation (consumption) in the planktonic microbial communities (de Angelis et al., 1991a), the results are not directly comparable with the effect of hydrostatic pressure on the methane oxidation activity of the $S$. crosnieri epibiotic methanotrophs. In addition, the planktonic microbial communities were collected from a water depth of approximately $2200 \mathrm{~m}$ (de Angelis et al., 1991a), whereas the S. crosnieri individuals and their epibionts are distributed at a water depth of $1000 \mathrm{~m}$. Both the samples were also decompressed once during sample recovery. Thus, it remains unclear whether hydrostatic pressure substantially affects in situ methanotrophic producti vity and methane oxidation by deep-sea vent microbial populations, and in situ labeled-tracer experiments or temperature- and pressure-preserved sampling and onboard measurement tools are necessary to better estimate these parameters. Nevertheless, our measurement of the methane oxidation activity provides the first rough estimation of the methane oxidation potential of $S$. crosnieri individuals and their epibiotic communities and provides insight into the biogeochemical and ecological significance of the dominant $S$. crosnieri populations in the large-scale carbon cycle of the methanedominant Okinawa Trough deep-sea hydrothermal systems.

The previous study clearly showed that the epibiotic community of $S$. crosnieri in the Iheya North field exhibited methanotrophic and thioautotrophic production (Watsuji et al., 2010). The ${ }^{13} \mathrm{C}$-labeled bicarbonate and methane incorporation into the epibiotic cellular compounds in the presence of thiosulfate and methane as the energy sources, respectively, suggested that the carbon fixation was approximately 1.9-fold greater via methane (methanotrophy) than bicarbonate (thioautotrophy) (Watsuji et al., 2010). This result seems to indicate that methanotrophic productivity in the epibiotic community dominates thioautotrophic productivity. However, as the incorporation experiments were conducted under aerobic conditions for a relatively longer time (48 h) (Watsuji et al., 2012), the thiotrophic productivity of the $\mathrm{O}_{2}$-sensitive filamentous Sulfurovum members (Nakagawa et al., 2005b; Macalady et al., 2008), as the predominant sulfur-oxidizing epibiont population, would be significantly inhibited by exposure to $\mathrm{O}_{2}$. On the other hand, the aerobic oxidation activity of reduced sulfur compounds of $S$. crosnieri individuals from the Iheya North field were estimated to be 550$580 \mu \mathrm{mol}$ sulfide $\mathrm{h}^{-1} \mathrm{~g}^{-1}$ dry weight of setae under both in situ and atmospheric pressures using the same continuous-flow incubation method used in this study (Watsuji et al., 2012). In this study, the aerobic methane oxidation activity of $S$. crosnieri individuals from the Iheya North field was determined to be 28-29 $\mu \mathrm{mol}$ methane $\mathrm{h}^{-1} \mathrm{~g}^{-1}$ dry weight of setae under both in situ and atmospheric pressures. These results seem to indicate that the sulfur oxidation activity of the epibiotic community potentially outcompetes the methane oxidation activity as the preferred mode of energy metabolism. However, these activity measurements may be conducted under different kinetic conditions of the metabolic functions (such as different substrate concentrations). It has been reported that the methane oxidation rate of cold seep Bathymodiolus sp. endosymbionts was highly variable with varying $\mathrm{CH}_{4}$ concentrations (up to $\left.300 \mu \mathrm{m}\right)($ Kochevar et al., 1992), and the sulfide oxidation rate of tubeworm Riftia pachyptila endosymbionts under high hydrostatic pressure was also affected by increasing sulfide concentrations (up to $600 \mu \mathrm{M}$ ) (Girguis and Childress, 2006). Therefore, the concentration ranges of dissolved reduced sulfur compounds and $\mathrm{CH}_{4}$ in in situ colonies are quite important to estimate properly the in situ metabolic potentials for $\mathrm{CH}_{4}$ and sulfur oxidation in the S. crosnieri populations with their epibionts, although it is very difficult to determine the highly fluctuating concentrations of these substrates in the widespread $S$. crosnieri colonies of the Iheya North field. In the previous studies, it has been indicated that long, thick filamentous Sulfurovum epibionts on $S$. crosnieri were thioautotrophs and that long, thin filamentous gamma-proteobacterial epibionts on S. crosnieri were potential thioautotrophs (Watsuji et al., 2010, 2012). This study suggests that short, thin filamentous morphotype of epibionts would be active type Ia methanotroph (Figure 1). It was already demonstrated by the FISH analysis targeting whole Epsilonproteobacteria, Gammaproteobacteria and specific type I methanotrophic Gammaproteobacteria that the cell abundances of long filamentous Sulfurovum and gamma-proteobacterial epibionts were significantly greater than the cell abundance of short filamentous potentially methanotrophic epibionts (Watsuji et al., 2010). Thus, based on the comparison of extant biomass abundances, it seems likely that the thioautotrophic productivity dominates the methanotrophic productivity in epibiotic community associated with $S$. crosnieri. As $S$. crosnieri is one of the predominant chemosynthetic macrofaunal populations in the Okinawa Trough deep-sea hydrothermal systems, the in situ metabolic rates and kinetic properties of thioautotrophy and methanotrophy of episymbiosis in the $S$. crosnieri populations will be key clues to 
understanding the biogeochemical cycles of carbon, nitrogen and sulfur associated with the hydrothermal activity. The metatranscriptomic quantification of various key energy and carbon metabolisms using in situ-fixed specimens shown in this study and reported by Sanders et al., (2013) will be one possible approach (Sanders et al., 2013). In addition, in situ continuous-flow or batch incubation experiments to estimate metabolic rates and kinetic properties will be featured in our future investigations.

\section{Conflict of Interest}

The authors declare no conflict of interest.

\section{Acknowledgements}

We are grateful to the crews of RV/Natsushima and the operation teams of DSV/HyperDolphin for helping us collect the deep-sea hydrothermal samples.

\section{References}

Campbell BJ, Stein JL, Cary SC. (2003). Evidence of chemolithoautotrophy in the bacterial community associated with Alvinella pompejana, a hydrothermal vent polychaete. Appl Environ Microbiol 69: 5070-5078.

Cary SC, Cottrell MT, Stein JL, Camacho F, Desbruyeres D. (1997). Molecular identification and localization of filamentous symbiotic bacteria associated with the hydrothermal vent annelid Alvinella pompejana. Appl Environ Microbiol 63: 1124-1130.

Chen Y, Dumont MG, McNamara NP, Chamberlain PM, Bodrossy L, Stralis-Pavese N et al. (2008). Diversity of the active methanotrophic community in acidic peatlands as assessed by mRNA and SIP-PLFA analyses. Environ Microbiol 10: 446-459.

Costello AM, Lidstrom ME. (1999). Molecular characterization of functional and phylogenetic genes from natural populations of methanotrophs in lake sediments. Appl Environ Microbiol 65: 5066-5074.

de Angelis MA, Baross JA, Lilley MD. (1991a). Enhanced microbial methane oxidation in water from a deep-sea hydrothermal vent field at simulated in situ hydrostatic pressures. Limnol Oceanogr 36: 565-570.

de Angelis MA, Reysenbach AL, Baross JA. (1991b). Surfaces of hydrothermal vent invertebrates: sites of elevated microbial CH4 oxidation activity. Limnol Oceanogr 36: 570-577.

Dedysh SN, Liesack W, Khmelenina VN, Suzina NE, Trotsenko YA, Semrau JD et al. (2000). Methylocella palustris gen. nov., sp. nov., a new methane-oxidizing acidophilic bacterium from peat bogs, representing a novel subtype of serine-pathway methanotrophs. Int $J$ Syst Evol Microbiol 50: 955-969.

Degelmann DM, Borken W, Drake HL, Kolb S. (2010). Different atmospheric methane-oxidizing communities in European beech and Norway spruce soils. Appl Environ Microbiol 76: 3228-3235.

Deutscher MP. (2006). Degradation of RNA in bacteria: comparison of mRNA and stable RNA. Nucleic Acids Res 34: 659-666.
Dumont MG, Pommerenke B, Casper P, Conrad R. (2011). DNA-, rRNA-and mRNA-based stable isotope probing of aerobic methanotrophs in lake sediment. Environ microbiol 13: 1153-1167.

Feike J, Jurgens K, Hollibaugh JT, Kruger S, Jost G, Labrenz M. (2012). Measuring unbiased metatranscriptomics in suboxic waters of the central Baltic Sea using a new in situ fixation system. ISME $J \mathbf{6}$ : 461-470.

Felsenstein J. (1985). Confidence limits on phylogenies: an approach using the bootstrap. Evolution 39: 783-791.

Frias-Lopez J, Shi Y, Tyson GW, Coleman ML, Schuster SC, Chisholm SW et al. (2008). Microbial community gene expression in ocean surface waters. Proc Natl Acad Sci USA 105: 3805-3810.

Girguis PR, Childress JJ. (2006). Metabolite uptake, stoichiometry and chemoautotrophic function of the hydrothermal vent tubeworm Riftia pachyptila: responses to environmental variations in substrate concentrations and temperature. J Exp Biol 209: 3516-3528.

Goffredi SK, Jones WJ, Erhlich H, Springer A, Vrijenhoek RC. (2008). Epibiotic bacteria associated with the recently discovered Yeti crab, Kiwa hirsuta. Environ Microbiol 10: $2623-2634$.

Grzymski JJ, Murray AE, Campbell BJ, Kaplarevic M, Gao GR, Lee C et al. (2008). Metagenome analysis of an extreme microbial symbiosis reveals eurythermal adaptation and metabolic flexibility. Proc Natl Acad Sci USA 105: 17516-17521.

Guri M, Durand L, Cueff-Gauchard V, Zbinden M, Crassous P, Shillito B et al. (2012). Acquisition of epibiotic bacteria along the life cycle of the hydrothermal shrimp Rimicaris exoculata. ISME J 6: 597-609.

Hery M, Singer AC, Kumaresan D, Bodrossy L, Stralis-Pavese N, Prosser JI et al. (2008). Effect of earthworms on the community structure of active methanotrophic bacteria in a landfill cover soil. ISME J 2: 92-104.

Heyer J, Berger U, Hardt M, Dunfield PF. (2005). Methylohalobius crimeensis gen. nov., sp. nov., a moderately halophilic, methanotrophic bacterium isolated from hypersaline lakes of Crimea. Soc General Microbiol 55: 1817-1826.

Heyer J, Galchenko VF, Dunfield PF. (2002). Molecular phylogeny of type II methane-oxidizing bacteria isolated from various environments. Microbiology 148: 2831-2846.

Holmes AJ, Costello A, Lidstrom ME, Murrell JC. (1995). Evidence that participate methane monooxygenase and ammonia monooxygenase may be evolutionarily related. FEMS Microbiol Lett 132: 203-208.

Huelsenbeck JP, Ronquist F. (2001). MRBAYES: Bayesian inference of phylogenetic trees. Bioinformatics 17: $754-755$.

Hugler M, Petersen JM, Dubilier N, Imhoff JF, Sievert SM. (2011). Pathways of carbon and energy metabolism of the epibiotic community associated with the deep-sea hydrothermal vent shrimp Rimicaris exoculata. PLoS One 6: e16018.

Jensen TE, Corpe WA. (1991). Ultrastructure of methylotrophic microorganisms. Biotechnology (Reading, MA) 18: $39-78$.

Kawagucci S, Chiba H, Ishibashi J, Yamanaka T, Toki T, Muramatsu Y et al. (2011). Hydrothermal fluid geochemistry at the Iheya North field in the midOkinawa Trough: implication for origin of methane in 
subseafloor fluid circulation systems. Geochem J 45: 109.

Kochevar RE, Childress JJ, Fisher CR, Minnich E. (1992). The methane mussel: roles of symbiont and host in the metabolic utilization of methane. Mar Biol 112: 389-401.

Kolb S, Knief C, Stubner S, Conrad R. (2003). Quantitative detection of methanotrophs in soil by novel pmoAtargeted real-time PCR assays. Appl Environ Microbiol 69: $2423-2429$.

Lindahl T. (1993). Instability and decay of the primary structure of DNA. Nature 362: 709-715.

Ludwig W, Strunk O, Westram R, Richter L, Meier H, Yadhukumar et al. (2004). ARB: a software environment for sequence data. Nucleic Acids Res 32: 1363-1371.

Macalady JL, Dattagupta S, Schaperdoth I, Jones DS, Druschel GK, Eastman D. (2008). Niche differentiation among sulfur-oxidizing bacterial populations in cave waters. ISME J 2: 590-601.

Murrell JC, McDonald IR, Gilbert B. (2000). Regulation of expression of methane monooxygenases by copper ions. Trends Microbiol 8: 221-225.

Nakagawa S, Takai K, Inagaki F, Chiba H, Ishibashi J, Kataoka S et al. (2005a). Variability in microbial community and venting chemistry in a sedimenthosted backarc hydrothermal system: impacts of subseafloor phase-separation. FEMS Microbiol Ecol 54: 141-155.

Nakagawa S, Takai K, Inagaki F, Hirayama H, Nunoura T, Horikoshi K et al. (2005b). Distribution, phylogenetic diversity and physiological characteristics of epsilonProteobacteria in a deep-sea hydrothermal field. Environ Microbiol 7: 1619-1632.

Polz MF, Cavanaugh CM. (1995). Dominance of one bacterial phylotype at a Mid-Atlantic Ridge hydrothermal vent site. Proc Natl Acad Sci USA 92: $7232-7236$.

Ponsard J, Cambon-Bonavita MA, Zbinden M, Lepoint G, Joassin A, Corbari L et al. (2012). Inorganic carbon fixation by chemosynthetic ectosymbionts and nutritional transfers to the hydrothermal vent hostshrimp Rimicaris exoculata. ISME J 7: 96-109.

Ronquist F, Huelsenbeck JP. (2003). MrBayes 3: Bayesian phylogenetic inference under mixed models. Bioinformatics 19: 1572-1574.

Saitou N, Nei M. (1987). The neighbor-joining method: a new method for reconstructing phylogenetic trees. Mol Biol Evol 4: 406-425.

Sanders JG, Beinart RA, Stewart FJ, Delong EF, Girguis PR. (2013). Metatranscriptomics reveal differences in in situ energy and nitrogen metabolism among hydrothermal vent snail symbionts. ISME J 7: 1556-1567.

Takai K, Horikoshi K. (2000). Rapid detection and quantification of members of the archaeal community by quantitative PCR using fluorogenic probes. Appl Environ Microbiol 66: 5066-5072.

Thurber AR, Jones WJ, Schnabel K. (2011). Dancing for food in the deep sea: bacterial farming by a new species of yeti crab. PLoS One 6: e26243.

Watsuji T, Nakagawa S, Tsuchida S, Toki T, Hirota A, Tsunogai U et al. (2010). Diversity and function of epibiotic microbial communities on the galatheid crab, Shinkaia crosnieri. Microb Environ 25: 288-294.

Watsuji T, Nishizawa M, Morono Y, Hirayama $H$, Kawagucci S, Takahata N et al. (2012). Cell-specific thioautotrophic productivity of epsilon-proteobacterial epibionts associated with Shinkaia crosnieri. PLoS One 7: e46282.

Wendeberg A, Zielinski FU, Borowski C, Dubilier N. (2012). Expression patterns of mRNAs for methanotrophy and thiotrophy in symbionts of the hydrothermal vent mussel Bathymodiolus puteoserpentis. ISME J 6: 104-112.

Wirsen CO, Jannasch HW, Molyneaux SJ. (1993). Chemosynthetic microbial activity at Mid-Atlantic Ridge hydrothermal vent sites. J Geophys Res 98: 9693-9703.

Zbinden M, Shillito B, Le Bris N, de Montlaur CD, Roussel $\mathrm{E}$, Guyot $\mathrm{F}$ et al. (2008). New insigths on the metabolic diversity among the epibiotic microbial communitiy of the hydrothermal shrimp Rimicaris exoculata. J Exp Mar Biol Ecol 359: 131-140.

Supplementary Information accompanies this paper on The ISME Journal website (http://www.nature.com/ismej) 